\title{
Anti-fungal, anti-oxidant, and anti-inflammatory effects of supercritical fluid extracts from Rosa multiflora root
}

\author{
Young Sim Go, Sun Eun Choi* \\ Department of Cosmetology Science, Nambu University, Gwangju 62271, Korea
}

\section{찔레뿌리 초임계 추출물의 항균, 항산화 및 항염증 활성}

\author{
고영심, 최선은* \\ 남부대학교 향장미용학과
}

\begin{abstract}
The roots of Rosa multiflora Thunberg have been used in traditional oriental medicine as remedies for rheumatic arthralgia and scabies. In this study, the anti-fungal, anti-oxidant, and anti-inflammatory activities of a supercritical extract of Rosa multiflora root were investigated in vitro. To investigate the anti-oxidant and anti-inflammatory effects of the supercritical extract, 2,2'-azino-bis(3-ethylbenzothiazoline-6-sulphonic acid (ABTS) radical scavenging activity, and the inhibition of nitric oxide production in lipopolysaccharide (LPS)-stimulated RAW 264.7 cells were examined, respectively. In addition, the anti-fungal activities of the extract were assessed. The results showed a concentration-dependent, increase in ABTS radical scavenging activity. The supercritical fluid extracts of Rosa multiflora root exhibited low toxicity to RAW 264.7 cells at $100 \mu \mathrm{g} / \mathrm{mL}$ the highest concentration tested. Cells stimulated with LPS produced more nitric oxide than normal control cells; however, cells treated with the supercritical fluid extract decreased this production in a concentration-dependent manner. Finally, the supercritical fluid extracts showed significant anti-fungal activity. These results suggest that extracts of the roots of Rosa multiflora might be used to develop potent anti-fungal, anti-oxidant, and anti-inflammatory agents, and may be useful as ingredients for related new functional cosmetic materials.
\end{abstract}

Key words : Rosa multiflora, supercritical fluid, anti-fungal, anti-oxidative, anti-inflammatory

\section{서 론}

장미과에 속하는 찔레나무는 한국, 일본, 중국을 포함하 여 동아시아 지역 야산에 광범위하게 분포하는 식물로서, 예로부터 찔레나무 열매는 토혈, 구갈증, 설사, 말라리아, 상처치유 등에 사용되어 왔으며, 찔레나무 뿌리는 당뇨병, 이질, 류마티스 관절통, 사지마비, 토혈, 비출혈, 빈뇨, 야뇨 증, 월경불순, 타박상, 옴 등의 증상에 민간요법으로 사용되 어 왔다(1).

*Corresponding author. E-mail : sechoi@nambu.ac.kr Fax : 82-62-443-1232

Received 18 January 2018; Revised 26 January 2018; Accepted 30 January 2018.

Copyright (c) The Korean Society of Food Preservation. All rights reserved.
찔레뿌리에 관한 성분 연구로는 tormentic acid와 그 배당 체를 분리 및 구조동정 연구를 시작으로(2) 그 외에 다양한 flavonoid 계열의 화합물 즉, multiflorin $\mathrm{A}$, multiflorin $\mathrm{B}$, multinoside $\mathrm{A}$, multinoside $\mathrm{A}$ acetate, quercetin, quercetin 3-O- $\beta$-D-xylopyranoside, quercetin 3-O- $\beta$-D-glucuronide methyl ester, isoquercitrin, hyperin, isorhamnetin $3-\mathrm{O}-\beta$ -D-glucoside, taxifolin 3-O- $\beta$-D-xylopyranoside, heliocioside $\mathrm{A}$ and 2-hydroxynaringin 5-O- $\beta$-D-glucopyranoside 등의 화 합물이 분리 및 구조동정 보고된바 있다(3-6). 최근 박 등은 찔레나무 뿌리로부터 2종의 신규 축합형 탄닌을 분리 및 구종동정을 하고 이들 화합물의 항산화 활성과 항염증, 항 아토피 활성을 보고하였다 $(8,9)$. 또한, 찔레나무 뿌리 용매 별 추출물의 항산화, 항염증 활성 연구와 acetone 유기용매 추출물로부터 2종의 poly-phenol 즉, procyanidin $\mathrm{B} 3$ 와 (+)-catechin을 분리하고 그들의 우수한 항상화 활성이 보고 
된 바 있다 $(10,11)$.

본 연구에서 활용된 초임계 추출 기술은 기존의 공정을 환경친화적인 방법으로 대체하려는 관련 산업계의 변화와 더불어 특히, 인체 적용을 목적으로 하는 생리활성 물질의 추출, 정제에 있어서 지속적으로 문제시 되어오는 유기용 매 사용에 대한 위해성, 환경독성 등의 문제점을 극복하기 위한 방법으로 알려져 있다. 초임계 유체 추출 기술을 천연 물 추출, 정제 분야에 적용하기 위해 국내외 많은 연구자들 에 의해 활용되어지고 있다(12-15).

초임계 유체 기술 중 이산화탄소는 낮은 임계 온도, 압력, 저렴한 비용, 무독성, 환경친화성 등의 장점을 이유로 가장 인기 높은 초임계 유체 기술로 잘 알려져 있다(15-18).

최근 본 연구자들은 기존 열수추출방법과 다양한 유기용 매를 활용하여 추출한 후 항산화 및 항염증 활성이 보고된 찔레나무뿌리를 대상으로 친환경적이고 기존에 밝혀지지 않은 찔레나무 뿌리 초임계 추출물의 항균활성, 항산화 및 항염증 활성 연구를 수행하여 천연물 유래 생리활성 기능성 신소재를 발굴하기 위해 본 연구를 수행하였다.

\section{재료 및 방법}

\section{실험재료 및 초임계 추출방법}

본 연구에서는 찔레나무 뿌리 추출은 초임계유체 추출 연구용 장비(ISA-SEFE-0500-0700-080, Ilsin Autoclave, Daejeon, Korea)를 사용하였다. 사용한 찔레나무 뿌리를 서 울약령시장에서 구입하여 이물질을 제거하고 세척한 후, 음건하여 실험재료로 사용하였다. 건조된 시료 $450 \mathrm{~g}$ 을 200 $\mathrm{mesh}$ 의 분쇄망을 통과하도록 분쇄하고, 분쇄된 찔레나무 뿌리를 추출조의 온도를 $50^{\circ} \mathrm{C}$ 로 조절하여 온도를 유지시킨 다. 온도가 안정화되면 찔레나무 뿌리 시료를 넣고 $\mathrm{CO}_{2}$ 가스를 등압으로 유지시킨 후, 고압펌프를 이용하여 line을 통해 실험압력 조건인 $400 \mathrm{bar}$ 에 도달할 때까지 control valve를 조절하여 주입하였다. 설정 압력에 도달 후 추출조 하부로 에탄올(HPLC grade)을 분당 $3 \mathrm{~mL}$ 씩 60 분 동안 총 $180 \mathrm{~mL}$ 를 투입하여 추출을 진행하였으며, 시료에 남아있 는 잔존 에탄올을 제거하기 위해 설정된 압력과 온도로 $30 \mathrm{~min}$ 동안 고압펌프를 이용하여 $\mathrm{CO}_{2}$ 를 흘려보내며 추출 을 완료 하였다.

본 실험에 사용된 lab-scale 초임계 유체추출장치의 개략 도를 Fig. 1에 나타내었다. Lab-scale 추출장치는 이산화탄 소의 공급을 위한 추출조, 분리조, 열교환기, 고압펌프 등으 로 구성되어져 있다.

\section{사용균주 및 균주 배양}

항균활성에 사용된 미생물 균주를 한국생명 공학연구원 생물자원센터(KCTC/BRC, Jeongeup, Korea), 한국미생물
보존센터(KCCM, Seoul, Korea)로부터 분양받았다, 실험에 사용한 각 미생물 균주의 균종과 번호를 Table 1 에 정리하 였다.

Table 1. List of microorganisms used for antimicrobial experiment

\begin{tabular}{ccccc}
\hline Strains & Culture collection & Gram strain & Media & Temp \\
\hline S.epidermidis & KCCM 35494 & Gram $(+)$ & TSB & $37^{\circ} \mathrm{C}$ \\
P. ovale & KCCM 12679 & Yeast & YMB & $37^{\circ} \mathrm{C}$ \\
T. mentagrophytes & KCCM11950 & Fungl & SGB & $26^{\circ} \mathrm{C}$ \\
\hline
\end{tabular}

Paper disc에 의한 찔레나무 뿌리 초임계 추출물의 항 균력 분석

항균력 검색은 paper disc법을 사용하였다(19). 배양된 균주는 $1.0 \times 10^{6} \mathrm{CFU} / \mathrm{mL}$ 으로 조절한 후 본 실험에 사용하였 다. 평판배지에 배양된 각 균주를 $100 \mu \mathrm{L}$ 씩 도말하여 준비 하였고, 추출물을 각각 $0.5-10 \mathrm{mg} / \mathrm{mL}$ 농도로 $40 \mu \mathrm{L}$ 씩 paper disc(diamerter $8 \mathrm{~mm}$, Roshi kaisha. Ltd., Tokyo, Japan) 에 천천히 흡수시킨 뒤 다음 $37^{\circ} \mathrm{C}$ 에서 24 시간 동안 배양하 였다. 대조군으로 에탄올을 사용하였으며, 배양 후 disc 주 변에 생성된 저해환(clear zone, $\mathrm{mm}$ )을 측정하여 항균활성 을 비교하였다.

\section{ABTS 래디칼 소거작용의 측정}

$\mathrm{ABTS}$ 래디칼 소거 활성은 $\operatorname{Re}$ 등(20)의 방법을 수정하여 측정하였다. ABTS(Sigma-Aldrich Co., St. Louis, MO, USA) 시약을 증류수에 용해하여 $7.0 \mathrm{mM}$ 의 농도로 준비하고, potassium persulfate(Sigma-Aldrich Co.)를 증류수에 용해하 여 $2.45 \mathrm{mM}$ 농도로 준비하여 두 용액을 $1: 1$ 비율로 섞어서 12-16시간 동안 암실상태로 방치하여 radical stock solution 을 제조하고 제조된 solution을 PBS buffer(pH 7.4)로 희석하 여 $750 \mathrm{~nm}$ 에서 흡광도를 측정하여 0.7-1.0 사이의 흡광값이 나오도록 희석하여 준비한다.

농도별로 시료를 준비하여 96-well plate에 sample:ABTS 반응 비율을 $1: 9$ 로 맞춰서 30 분 동안 암실에서 반응을 시키 고, 반응이 끝난 후 $750 \mathrm{~nm}$ 파장에서 흡광도를 측정한다.

\section{Mouse macrophage RAW 264.7 cell 배양}

Mouse macrophage RAW 264.7 cell은 한국 세포주 은행 에서 동결상태로 구입하였으며 cell이 들어있는 앰플을 미 온수 $\left(30-40^{\circ} \mathrm{C}\right)$ 에 바로 녹여 $10 \% \mathrm{FBS}$ (fetal bovine serum), penicillin $\mathrm{G}(100 \mathrm{IU} / \mathrm{mL})$, streptomycin $(100 \mu \mathrm{g} / \mathrm{mL})$ 을 포함한 $\mathrm{DMEM}$ 배지를 이용하여 동결 과정에서 넣어준 $\mathrm{DMSO}$ 를 제거하고, DMSO를 제거한 RAW 264.7 cells에 DMEM을 $5 \mathrm{~mL}$ 넣어, 온도 $37^{\circ} \mathrm{C}$ 와 $5 \%$ 의 $\mathrm{CO}_{2}$ 를 유지하면서 incubator 에서 배양하였으며, 1-2일마다 세포의 성장 정도에 따라 계대 배양하였다. 


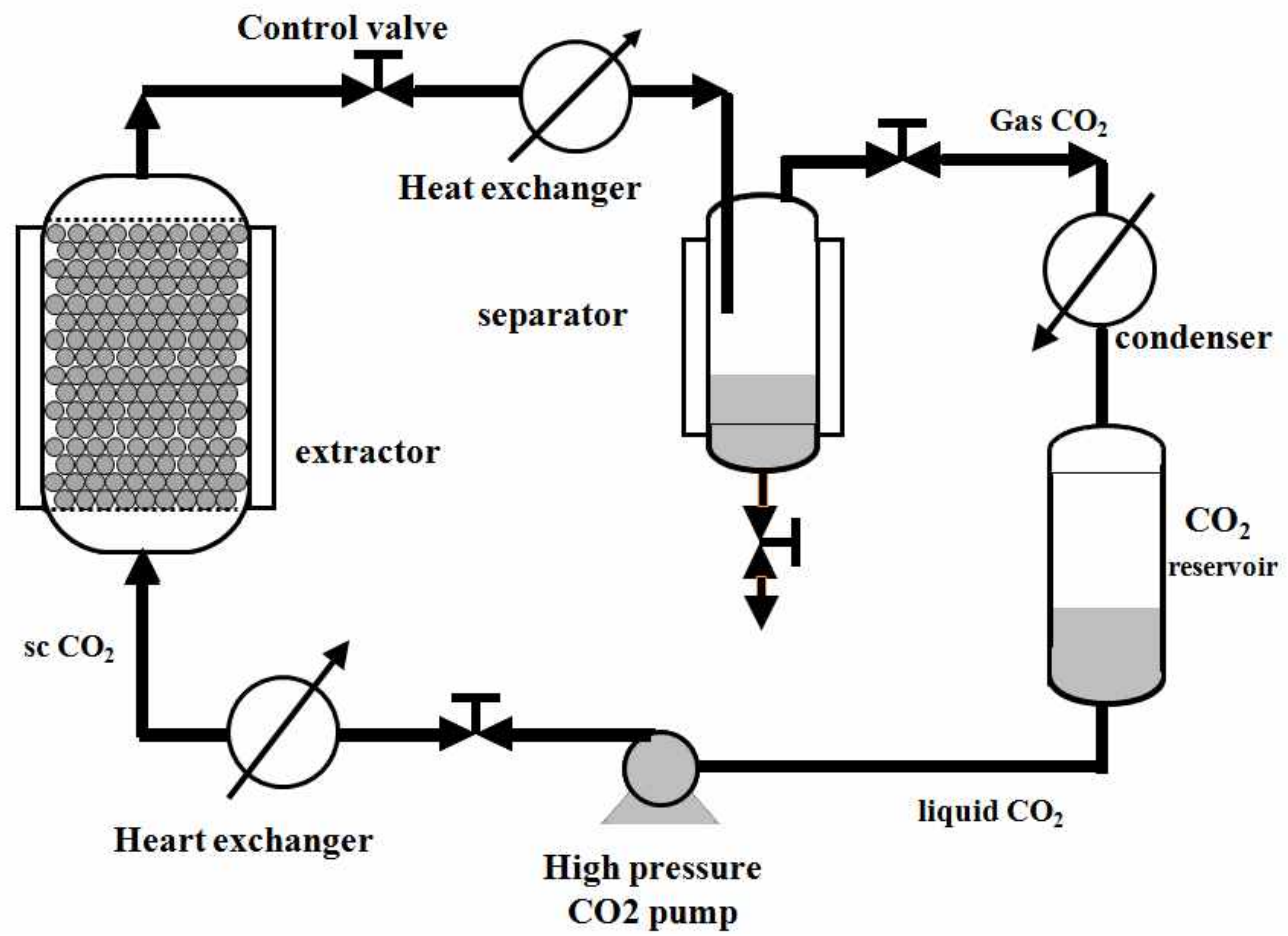

Fig. 1. Schematic diagram of the supercritical fluid extracts apparatus.

\section{MTT assay}

본 실험에서 RAW 264.7 cells에 대한 찔레뿌리 초임계 추출물의 세포 독성 및 실험 시 처리 농도를 결정하기 위해 MTT assay를 실행하였다. RAW 264.7 cells을 DMEM으로 medium $1 \mathrm{~mL}$ 당 $5 \times 10^{4}$ 개만큼 배양시킨 다음, $1 \mathrm{~mL}$ 당 $1 \times 10^{4}$ 개로 희석하여 96-well에 $180 \mu \mathrm{L}$ 씩 넣고 2시간 동안 배양하여 cell들이 부착되도록 하고, 부착된 cells 배양액에 각각의 시료를 $20 \mu \mathrm{L}$ 씩 넣은 후 24시간 동안 배양하였다. 24 시간 배양 후, 새로운 medium으로 교체하고 미리 조제한 MTT를 최종 농도가 $0.5 \mathrm{mg} / \mathrm{mL}$ 가 되게 첨가한 후, 보라색으 로 생성된 formazan의 양을 정량하였다.

\section{Nitric oxide 생성 억제 작용 측정}

Nitric oxide 생성 억제 작용은 Griess의 방법(22,23)으로 측정하였다. 즉, Griess reagent $(1 \%$ sulfanilamine, $0.1 \%$ $\mathrm{N}$-(1-naphthyl)-ethylene diamine dihydrochloride, $2.5 \%$ $\mathrm{H}_{3} \mathrm{PO}_{4}$ )는 $\mathrm{NO}$ 를 산화시켜 $\mathrm{NO}_{2}$ 로 변화시키며 생성된 $\mathrm{NO}_{2}$ 는 $540 \mathrm{~nm}$ 에서 흡광도를 측정하여 그 농도를 $\mathrm{NaNO}_{2}$ 의 검량선을 이용하여 구하였다.

즉, RAW 264.7 cell을 $\mathrm{DMEM}$ 으로 medium $1 \mathrm{~mL}$ 당 $5 \times 10^{4}$ 개 만큼 배양시킨 다음, $1 \mathrm{~mL}$ 당 $1 \times 10^{4}$ 개로 희석하여 96-well에 $160 \mu \mathrm{L}$ 씩 넣고 2시간 동안 배양해서 cell들이 부착 되도록 한 다음 $\mathrm{LPS}(1 \mu \mathrm{g} / \mathrm{mL}) 10 \mu \mathrm{L}$ 을 포함한 각각의 시료 를 $20 \mu \mathrm{L}$ 씩 넣고 20시간 배양시킨 후, 배양액에 생성되어 있는 $\mathrm{NO}$ 의 양을 Griess reagent를 이용하여 정량하였다.
총 페놀 함량

총 페놀 함량은 Folin-Denis법(24)에 따라 각 추출물 1 $\mathrm{mL}$ 에 Folin-Ciocalteu 시약 및 $10 \% \mathrm{Na}_{2} \mathrm{CO}_{3}$ 용액을 각 $1 \mathrm{~mL}$ 씩 차례로 가한 다음 실온에서 1시간 정치시킨 후 ELISA reader(TECAN, Salzburg, Austria)를 사용하여 $700 \mathrm{~nm}$ 에서 흡광도를 측정하였다. 표준물질로 gallic acid와 ethyl gallate 를 사용하여 시료와 동일한 방법으로 분석하여 얻은 검량선 으로부터 총 페놀 함량을 산출하였다.

\section{통계 처리}

본 연구의 실험 결과들은 3회 반복 측정하여 평균값 \pm 표 준편차로 나타내었으며, 모든 자료의 통계처리는 SPSS (Statistical Package for Science, version 24.0 SPSS Inc, Chicago, IL, USA)를 사용하여 처리하였다. 각 실험 농도 별 표준차이를 검증하기 위해 분산분석을 수행하였으며, 유의성이 발견된 경우 Tukey's HSD test(25)에 의해 농도 간의 유의성을 분석하였다.

\section{결과 및 고찰}

\section{찔레나무뿌리 초임계 추출물의 항균효과}

Staphylococcus epidermidis (S. epidermidis) 는 정상인 피 부에서도 관찰되지만 모공이 막힌 경우 급격하게 증식하여 염증을 유발하는 것으로 알려져 있다. 피부가 염증에 노출 
될 경우 미생물 침입을 방어하는 방어 기작 또한 약해지고 2 차적인 피부장벽의 약화를 발생시키고, 또 다른 미생물 감염의 원인이 되어 악순환이 반복된다(26). 찔레나무 뿌리 초임계 추출물의 S. epidermidis에 대한 항균효능을 확인하 기 위해 균의 생육저해환인 clear zone(mm)을 측정한 결과 Fig. 2A와 같이 나타났다. $500 \mathrm{\mu g} / \mathrm{mL}-10 \mathrm{mg} / \mathrm{mL}$ 농도에서 찔레나무 뿌리 초임계 추출물은 모든 농도에서 clear zone(mm)이 9, $12 \mathrm{~mm}$ 로 각각 항균력이 확인 되었다(Table 2). 실험 농도 중 $500 \mu \mathrm{g} / \mathrm{mL}-5 \mathrm{mg} / \mathrm{mL}$ 농도에서는 $9 \mathrm{~mm}$ 로 저해환이 확인이 되었지만, 강력하거나 뚜렷한 항균활성이 확인되지 않았고, 농도 의존적으로 항균력이 증가하지는 못하였으나, 실험 최고 농도인 $10 \mathrm{mg} / \mathrm{mL}$ 농도에서부터는 명확하게 항균력이 확인이 되어서 향후 해당 균종을 대상으 로 유효한 항균력을 기대하려면 최소한 $10 \mathrm{mg} / \mathrm{mL}$ 이상의 농도에서 사용해야 할 것으로 사료된다.
정한 결과 Fig. $2 \mathrm{~B}$ 와 같이 나타났다. $1-10 \mathrm{mg} / \mathrm{mL}$ 농도에서 찔레나무 뿌리 초임계 추출물은 농도의존적으로 항균력이 증가되는 것이 확인 되었다. 항균력 확인된 농도에서 각각 $10,11,12 \mathrm{~mm}$ clear zone이 확인 되어 농도가 높아짐에 따라서 해당 균종에 대해서 항균력이 높아지는 것을 확인할 수 있었다(Table 2).

무좀의 원인균은 Trichophyton sp.이며, 주원인균으로는 T. mentagrophytes와 T. rubrum이 알려져 있다(28). 기존에 밝혀진 연구들을 통해서 Trichophyton 균은 무좀 및 아토피 피부병, 비염 및 천식으로 이루어진 알레르기성 질환군을 유발하는 것으로 알려져 있다(29,30).

찔레나무 뿌리 초임계 추출물의 T. mentagrophytes에 대 한 항균효능을 확인하기 위해 균의 생육저해환을 측정한 결과 $\mathrm{Fig} .2 \mathrm{C}$ 와 같이 나타났다. 찔레나무 뿌리 초임계 추출 물은 5 와 $10 \mathrm{mg} / \mathrm{mL}$ 의 농도에서 각각 $10,13 \mathrm{~mm}$ 의 clear

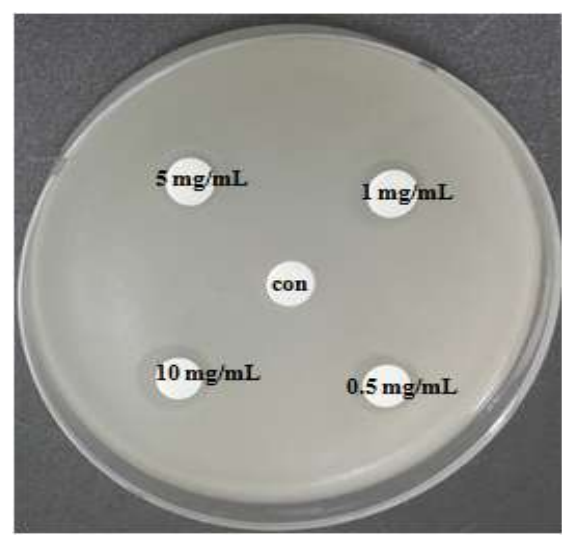

S. epidermidis

A

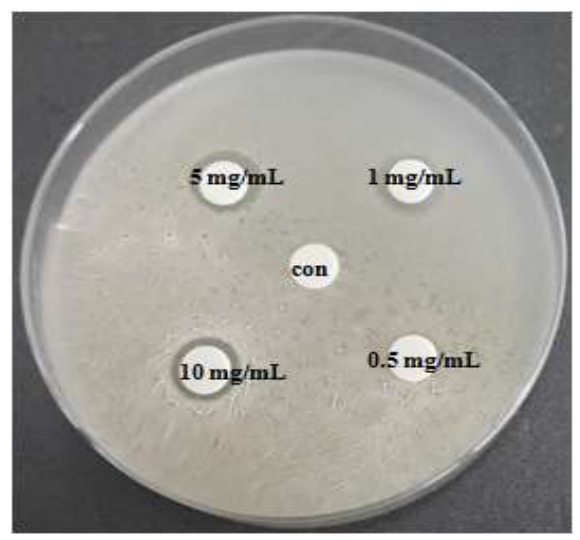

P. ovale

$\mathrm{B}$

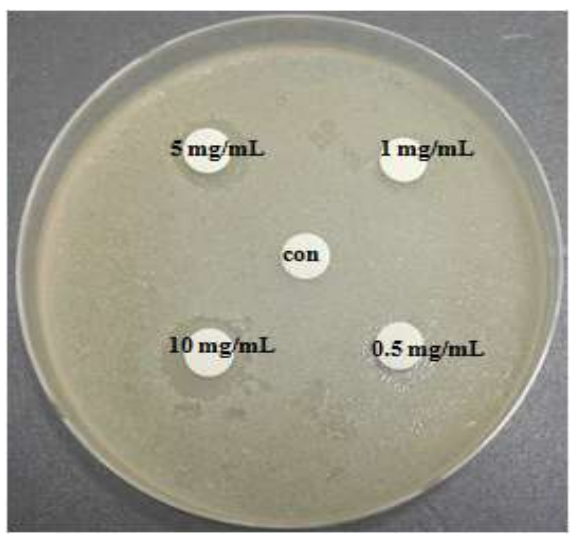

T. mentagrophytes

$\mathrm{C}$

Fig. 2. Inhibitory activities of supercritical extraction of Rosa multiflora Root against $S$. epidermidis, P. ovale and T. mentagrophytes.

Table 2. Antimicrobial activity of supercritical extraction of Rosa multiflora Root

\begin{tabular}{cccc}
\hline & \multicolumn{4}{c}{ Microorganisms } \\
\cline { 2 - 4 } $\begin{array}{c}\text { Concentration } \\
(\mathrm{mg} / \mathrm{mL})\end{array}$ & S. epidermidis & P. ovale & T. mentagrophytes \\
\cline { 2 - 4 } & \multicolumn{3}{c}{ Clear zone diameter $(\mathrm{mm})$} \\
\hline 0.5 & 9 & - & - \\
1 & 9 & 10 & - \\
5 & 9 & 11 & 10 \\
10 & 12 & 12 & 13 \\
\hline
\end{tabular}

피부에 가려움증을 동반한 지루성 피부병을 유발하는 것으로 잘 알려진 비듬균은 과도한 땀 분비와 스트레스 등에 의해 영향을 많이 받는 것으로 잘 알려져 있다(27). 찔레나무 뿌리 초임계 추출물의 P. ovale에 대한 항균효능 을 확인하기 위해 균의 생육저해환인 clear zone $(\mathrm{mm})$ 을 측 zone을 형성하여 T. mentagrophytes에 대한 항균력이 있음 을 확인할 수 있었다(Table 2). 이러한 결과를 통해서 찔레나 무 뿌리 초임계 추출물은 $5 \mathrm{mg} / \mathrm{mL}$ 의 농도 이상에서 $T$. mentagrophytes에 의해 유발되는 무좀 및 아토피 피부염, 비염과 천식 등을 포함한 알러지성 질환을 예방 및 치료를 위한 기능성 소재로 활용될 수 있는 가능성이 있음을 확인 할 수 있었다.

\section{ABTS 래디칼 소거능 활성}

찔레나무 뿌리 초임계 추출물의 ABTS radical 소거능을 비교한 결과는 Fig. 3과 같다. 찔레나무 뿌리 초임계 추출물 을 $0.1 \mathrm{mg} / \mathrm{mL}$ 부터 $500 \mathrm{mg} / \mathrm{mL}$ 까지 측정한 결과 모든 실험 농도에서 농도 의존적으로 유의적인 $\mathrm{ABTS}$ 라디컬 소거능 이 관찰 되었다. 특히, 실험 최고 농도인 $500 \mathrm{mg} / \mathrm{mL}$ 에서는 양성 대조군인 비타민 $\mathrm{C}$ 의 항산화 활성이 더 우수한 것으로 
확인되었다. 이러한 결과로서 찔레나무 뿌리 초임계 추출 물이 산화적 스트레스로 인해 유발하는 노화, 알러지질환, 피부질환을 포함한 다양한 난치성 질환을 예방 및 치료에 도움을 줄 수 있는 신규 천연항산화제로 개발이 가능할 것으로 사료된다.

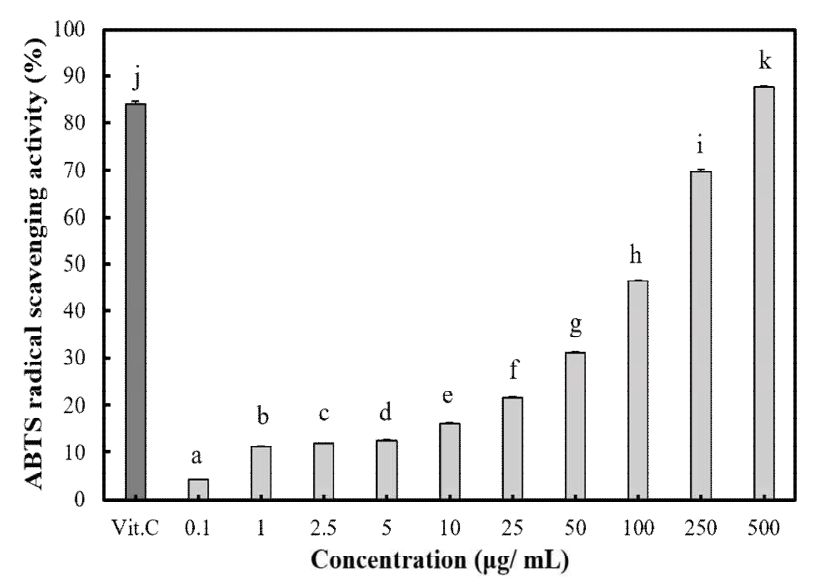

Fig. 3. ABTS radical scavenging activities of supercritical extraction of Rosa multiflora Root.

Values are means $\pm \mathrm{SD}$ of triplicate determinations. Different superscripts within a column indicate significant differences $(\mathrm{p}<0.05)$.

\section{Nitric oxide(NO) 소거능}

과 생성된 $\mathrm{NO}$ 에 의해서 류마티스 관절염, 아토피피부염 등과 같은 난치성 피부면역 질환의 염증반응이 악화시키므 로 유해한 작용을 나타내게 된다. 염증성 자극의 반응에 의한 $\mathrm{NO}$ 생성의 저해는 만성염증성 피부면역 질환에서 치 료적 방법으로 중요한 영역으로 인지되고 있다(32). 찔레나 무 뿌리 초임계 추출물의 난치성 피부면역 질환 소재로서

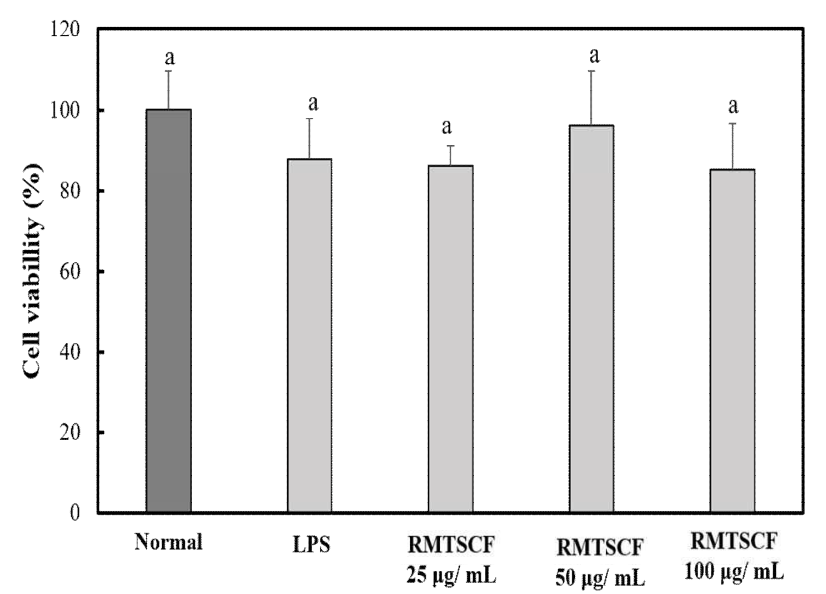

Fig. 4. Effects of supercritical extraction of Rosa multiflora Root on the viability of mouse RAW 264.7 macrophage cells.

The cell viability was measured by MTT assay. Results were expressed as \% of control absorbance. Values are means \pm SD of triplicate determinations. Different superscripts within a column indicate significant differences $(p<0.05)$.
활용 가능성을 확인하기 위해서 Raw 264.7 macrophage cell line에서 LPS로 유도된 NO 생성 억제능을 실험하기에 앞서 실험에 사용된 농도 25-100 $\mathrm{\mu g} / \mathrm{mL}$ 모든 농도에서 MTT assay를 통해서 세포 독성을 확인해 본 결과는 Fig. 4에서와 같이 모든 실험군에서 찔레뿌리 초임계 추출물의 첨가에 따른 세포활성 억제가 관찰되지 않았다. 찔레나무 뿌리 초 임계 추출물의 NO 소거능을 확인해 본 결과는 Fig. 5 에 나타내었다. 즉, 실험에 사용된 모든 농도에서 음성 대조군 인 LPS 유도군에 비해서 통계적으로 유의성 있게 NO 소거 능이 확인이 되었으며, Normal 대조군과 비교하였을 때 찔레나무 뿌리 초임계 추출물은 NO 소거능이 매우 강한 것으로 확인되어, 신규 천연물 유래 항염증 활성 소재로 개발이 가능할 것으로 사료되며, 특히 만성 염증성 피부면 역 질환에 적용이 가능할 것으로 사료된다.

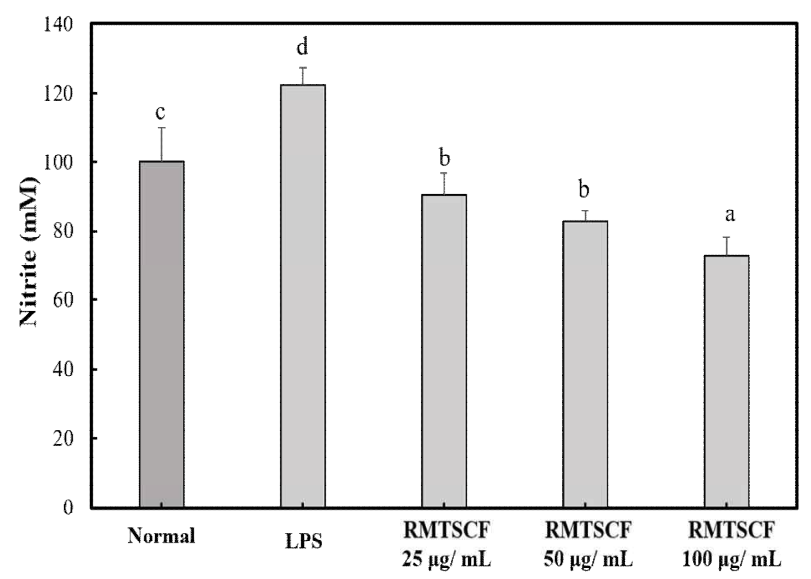

Fig. 5. NO contents of each supercritical extraction of Rosa multiflora Root in LPS stimulated mouse RAW 264.7 macrophage cells.

Values are means $\pm \mathrm{SD}$ of triplicate determinations. Different superscripts within a column indicate significant differences $(\mathrm{p}<0.05)$.

\section{총 페놀 함량}

식물유래 polyphenol 화합물은 식물의 이차대사산물로 서 항산화 활성을 기반으로 노화, 면역력 감소로 인한 다양 한 질환을 예방하고 증상을 완화시켜 주는 것으로 알려져 있다 $(33,34)$. 본 실험에서는 총 페놀 함량을 측정하기 위해 서 페놀 화합물의 표준물질로 가장 보편적으로 잘 활용되고 있는 gallic acid와 ethyl gallate를 각각 사용하여 Folin-Denis 법(24)에 의해 구해진 검량선 으로부터 총 페놀 함량을 Table 3 과 같이 확인이 되었다. 이러한 결과로 인해서 신규 천연 항산화제로서의 가치가 있을 것으로 기대가 된다. 하 지만, 초임계 추출물이 항산화 활성 실험에서는 상대적으 로 고농도에서 활성이 확인되고, NO 억제능 실험인 cell line에서는 저농도에서도 강력한 활성을 나타내는 원인에 대해서는 향후 지속적인 성분 연구를 통하여 찔레나무 뿌리 
초임계 추출물의 생리활성을 나타낸 단일 화합물을 밝혀나 가야 할 것으로 사료된다.

Table 3. Total phenolic contents of supercritical extraction of Rosa multiflora Root (mg/g)

\begin{tabular}{cc}
\hline Groups $^{1)}$ & Phenol \\
\hline TPCEG & $12.76 \pm 0.17^{2)}$ \\
TPCGA & $9.59 \pm 0.08$ \\
\hline
\end{tabular}

${ }^{11)}$ PPCE, total polyphenol contents ethyl gallate; TPCGA, total polyphenol contents gallic acid.

2)All values in Table are mean $\pm \mathrm{SD}$

\section{요 약}

신규 천연물 유래 난치성 피부면역 질환 기능성 소재를 발굴하기 위해서 찔레나무 뿌리를 초임계 유체 기술을 활용 하여 추출을 수행하였고, 확보된 찔레나무 뿌리 초임계 추 출물을 대상으로 3종의 피부상재균(Staphylococcus epidermidis, Pityrosporum ovale, Trichophyton mentagrophytes)에 대하 여 항균력을 확인한 결과 추출물은 시험된 모든 균종에 대해 항균력이 확인이 되어서 각 균으로 유발될 수 있는 질환으로 알려진, 무좀 및 아토피 피부병, 비염 및 천식으로 이루어진 알레르기성 질환, 염증성 피부질환, 비듬 등의 질환을 예방 및 치료 보조 수단으로 활용이 가능할 것으로 기대된다. 또한, $\mathrm{ABTS}$ 라디컬 소거능과 $\mathrm{NO}$ 소거능 실험을 통해서 찔레나무 뿌리 초임계 추출물의 항산화 활성과 항염 증 활성의 우수한 활성이 확인이 되어서 산화적 스트레스 질환과 염증성 질환에 대해서 예방 및 치료 보완 신소재로 개발이 가능성이 높다는 것을 알 수 있었다. 결론적으로 찔레나무 뿌리 초임계 추출물은 피부상재균에 대한 항균활 성, 라디컬 소거능에 의한 항산화 활성, 과 생성된 $\mathrm{NO}$ 소거 능에 의한 항염증활성이 각각 확인이 되어 향후 만성 염증 성 피부면역 질환 개선 및 치료 보조제 관련 의약품 또는 기능성 향장품 개발 관련 신소재로 활용이 가능한 소재로 판단된다.

\section{감사의 글}

이 논문 2017년도 정부(과학기술정보통신부)의 재원으 로 한국연구재단의 지원을 받아 수행된 연구임(No. NRF-2017R1C1B5016051).

\section{References}

1. Kim CM, Shin MK, Ahn DK, Lee KS (1998) An
Unabridged Dictionary of Chinese Herbs. Jeongdam Publishing House, Seoul, Korea, p 4735-4738

2. Takahashi K, Ogura M, Tanabe Y (1969) Studies on constituents of medicinal plants. IX. A constituent of the roots of Rosa multiflora Thunb. Chem Pharm Bull, 17, 2223-2229

3. Takagi S, Yamaki M, Masuda K, Kubota M (1976) On the constituents of the fruits of Rosa multiflora Thunb. I. Yakugaku Zasshi, 96, 284-288

4. Takagi S, Yamaki M, Masuda K, Kubota M (1976) On the constituents of the fruits of Rosa multiflora Thunb. II. Yakugaku Zasshi, 96, 1217-1222

5. Huang TK, Ding ZZ, Zhao SX, Yan YQ, Xu GJ, Chen L, Yu CL, Gao XL, Zhang ZD (2001) Compendium of modern materia medica. China Medico Pharmaceutical Science \& Technology Publishing House, Beijing, China, p 2473-2474

6. Seto T, Yasuda I, Akiyama K (1992) Purgative activity and principals of the fruits of Rosa multiflora and $R$ wichuraiana. Chem Pharm Bull, 40, 2080-2082

7. Kawakami S, Matsunami K, Otsuka H, Kawahata M, Yamaguchi K (2009) Chemical constituents of imported rosae fructus. J Nat Med, 63, 46-51

8. Park KH, Kim SK, Choi SE, Kwon JH, Oh MH, Lee MW (2010) Three new stereoisomers of condensed tannins from the roots of Rosa multiflora. Chem Pharm Bull, 58, 1227-1231

9. Park KH, Choi SE, Choi YW, Lee DI, Joo SS, Jeong MS, Bang H, Lee CS, Lee MK, Seo SJ, Lee MW (2011) Topical application of two condensed tannins from the root of Rosa multiflora Thunberg for the treatment of atopic dermatitis (AD) in NC/Nga mice, Phytother Res, $25,1564-1569$

10. Han JT (2006) Development of functional material using the root of Rosa multiflora, Food ind nutr, 11, 59-65

11. Park GH, Lee JY, Kim DH, Cho YJ, An BJ (2011) Anti-oxidant and antiinflammatory effects of Rosa multiflora root. J Life Sci, 21, 1120-1126

12. Bevan CD, Marshall PS (1994) The use of supercritical fluids in the isolation of natural products. Nat Prod Rep, 11, 451-466

13. Chester TL, Pinkston JD, Raynie DE (1994) Supercritical fluid chromatography and extraction. Anal Chem, 66, 106-130

14. Modey WK, Mulholland DA, Raynor MW (1995) Analytical supercritical fluid extraction of natural products. Phytochem Anal, 7, 1-15 
15. McHugh MA, Krukonis VJ (1994) Supercritical fluid extraction: Principles and practice, $2^{\text {nd }}$ ed, ButterworthHeinemann, Boston, MA, USA, p 1-16

16. Hoyer GG (1985) Extraction with supercritical fluids: why, how and so what, Chemtech, 7, 440-448

17. Stahl E, Quirin KW, Gerard D (1988) Dense gases for extraction and refining. Springer Verlag, Berlin, Germany, p 173

18. Choi YH, Park EJ, Kim YL, Chin YW, Kim JW, Jeon SH, Joung SN, Yoo KP (1999) Selective extraction of cytotoxic substances from medicinal plants using supercritical carbon dioxide. Korean J Pharmacogn, 30, 59-64

19. Davidson PM, Parish ME (1989) Methods for testing the efficacy of food antimicrobials. Food Technol, 43, 148-155

20. Re R, Pellegrini N, Proteggente A, Pannala A, Yang M, Rice-Evans C (1999) Antioxidant activity applying an improved ABTS radical cation decolorization assay. Free Rad Biol Med, 26, 1231-1237

21. Mosmann T (1983) Rapid colorimetric assay for the cellular growth and survival. J Immunol Methods, 65, 55-63

22. Feelisch M, Stamler J (1996) Methods in nitric oxide research, John Wiley \& Sons, Chichester, UK, p 492-497

23. Park SY, Hong SS, Han XH, Ro JS, Hwang BY (2005) Inhibitory constituents of LPS-induced nitric oxide production from Arctium lappa, Nat Prod Sci, 11, 85-88

24. Folin O, Denis W (1912) On phosphotungsticphosphomolybdic compounds as color reagent, J Biol chem, 12, 239-243

25. Steel RGD, Torrie JH (1980) Principle and procedures of statistics. $1^{\text {st }}$ ed. Kogakusha, McGraw-Hill, Tokyo, Japan, p 187- 221

26. Lee BE, Yang JC, Kim BA (2016) A Study of Antioxidative and Antimicrobial Effects of Coffee Residue Extracts. J Korean Oil Chem Soc, 33, 606-613

27. Lee IH, Kim MJ, Choi JH, Choi SH (2010) Antifungal effect of bilobalide and ginkgolide extracted from leaves of Ginkgo biloba Against Pityrosporum ovale, KSBB J, 25, 173-178

28. Lee SK (2003) Antimicrobial effect of bamboo (Phyllosrachys Bambusoides) essential oil on Trichophyton and Pityrosporum. J Food Hyg Saf, 18, 113-117

29. Kim SS, Lee SK, Nahm DH, Park HS (2001) Trichophyton and asthma : specific IgE, IgG1 and IgG4 determination. Korean J Asthma Allergy Clin Immunol, 21, 241-249

30. Kivity S, Schwarz Y, Fireman E (1992) The association of perennial rhinitis with Trichophyton infection. Clin Exp Allergy, 22, 498-500

31. Miller NJ, Rice-Evans C, Davies MJ, Gopinathan V, Milner A (1993) A novel method for measuring antioxidant capacity and its application to monitoring the antioxidant status in premature neonates. Clinical Sci, 84, 407-412

32. Kharitonov S, Yates D, Robbins RA, Logan-Sinclair R Shinebourne EA, Barnes PJ (1994) Increased nitric oxide in exhaled air of asthmatic patients, Lancet, 343, 133-135

33. Nakatani N (1990) Recent advances in the study on natural antioxidants. Jpn Soc Food Sci Technol, 37, 569-576

34. Nozaki K (1986) Current aspect and future condition of phytogenic antioxidants, Fragrance J, 6, 99-106 